\title{
MENGEMBANGKAN KEMAMPUAN PEMECAHAN MASALAH MELALUI PEMBELAJARAN STRATEGI HEURISTIK DENGAN PENDEKATAN METAKOGNITIF DITINJAU DARI KEMANDIRIAN BELAJAR MAHASISWA CALON GURU MATEMATIKA
}

\author{
Yudi Darma dan Muhamad Firdaus \\ Program Studi Pendidikan Matematika, IKIP PGRI Pontianak \\ e-mail: yudidarmamtk@gmail.com
}

\begin{abstract}
This study intends to develop heuristic strategies in learning courses based on statistical data analysis metacognitive approach. This study was a quasi-experimental study with $2 \times 3$ factorial design. Techniques of data analysis, namely: balance test, test requirements analysis (test for normality and homogeneity test), test research hypotheses using two way analysis of variance with unequal cells. Based on the research results, it was concluded that that: 1) Students are provided with the learning of metacognitive have problem-solving ability is better than the conventional learning; 2) Students who have a high learning independence have problem solving skills better than students who have low learning independence, and students who have moderate learning independence as well as problem solving skills of students who have learning independence high and low; 3) Based on the categories of metacognitive and conventional learning, students who have a higher learning independence acquire mathematical problem solving ability is better than the lower learning independence, while the mathematical problem solving ability of students who have moderate learning independence as well as low learning independence; 4) Based on the category of high-independent learning, students who applied to acquire metacognitive learning mathematical problem solving abilities better than that applied by conventional learning. Based category learning independence medium or low, there is no difference mathematical problem solving ability of students who applied to the metacognitive learning and conventional learning.
\end{abstract}

Key Words: Strategy Heuristic, Metacognitive, Conventional, Independent Learning, Problem Solving Ability

\begin{abstract}
Abstrak: Penelitian ini bertujuan untuk membangun strategi heuristik dalam pembelajaran berbasis pendekatan metakognitif pada mata kuliah Analisis Data Statistik. Penelitian ini merupakan penelitian eksperimen dengan desain faktorial $2 \times 3$. Teknik analisis data yang digunakan adalah analisis variansi dengan dua sel tak sama. Berdasarkan hasil penelitian, disimpulkan bahwa:1) siswa yang diberikan metode metakognitif memiliki kemampuan menyelesaikan masalah lebih baik dibandingkan metode konvensional. 2) siswa dengan kecenderungan belajar mandiri tinggi memiliki kemampuan menyelesaikan masalah lebih baik dari pada siswa dengan kecenderungan kemandirian rendah dan sedang, 3) berdasarkan kategori pembelajaran metakognitif dan konvensional, siswa dengan kecenderungan kemandirian belajar tinggi, mempunyai kemampuan menyelesaikan masalah lebih baik dari pada siswa dengan kemandirian belajar yang rendah, demikian pula dengan siswa yang memiliki kemampuan meyelesaikan soal matematika dari siswa yang memiliki kemandirian belajar sedang. 4) berdasarkan kategori kemandirian belajar tinggi, kemampuan ini bisa dengan cepat diperoleh oleh siswa yang menggunakan metode metakognitif dibandingkan dengan siswa yang menggunakan metode konvensional. Berdasarkan tingkatan kemandirian belajar tingkat menengah dan rendah, tidak terdapat perbedaan diantara keduanya baik yang menggunakan metode metakognitif maupun konvensional.
\end{abstract}

Kata Kunci: Strategi Heuristik, Metakognitif, Konvensional, Kemandirian Belajar, Kemampuan Menyelesaikan Masalah 


\section{PENDAHULUAN}

Perubahan dalam pembelajaran matematika telah mengalami perubahan, tidak lagi hanya menekankan pada peningkatan hasil belajar, namun juga diharapkan dapat meningkatkan kemampuan: (1) komunikasi matematika (mathematical communication); (2) penalaran matematika (mathematical reasoning); (3) pemecahan masalah matematika (mathematical problem solving); (4) mengkaitkan ide-ide matematika (mathematical connections); (5) representasi matematika (mathematical representation) (National Council of Teaching Mathematics, 2000).

Dengan penekanan pada kemampuan matematika mahasiswa, beberapa penelitian menyatakan jenis penyelesaian yang digunakan mahasiswa antara lain: melihat soal secara sepintas, memutuskan dengan cepat kalkulasi apa yang digunakan untuk memanfaatkan bilangan yang diberikan pada soal, kemudian meneruskan perhitungan tanpa mempertimbangkan alternatif lainnya, sehingga belum ada kemajuan yang ditunjukkan pada hasil pekerjaannya (Corte et al, 1996; Greer, 1992). Dengan demikian dapat dikemukakan bahwa mahasiswa belum mampu menggunakan strategi penalaran dalam menyelesaikan soal aplikasi matematis.

Selain itu, dengan penekanan pada aspek afektif, beberapa penelitian berhasil mengidentifikasi bahwa sebagian besar mahasiswa memiliki kekurangan dalam mendukung kemajuan pengajaran dan pembelajaran matematika serta pemecahan masalah. Sikap yang ditunjukkan ini merupakan pengaruh negatif bagi kesadaran mahasiswa untuk melibatkan diri dalam aktivitas pemecahan masalah. Ketika menghadapi soal matematika, pada jenis pengetahuan yang diujikan untuk mereka manfaatkan dalam penyelesaian soal, dan pada suatu cara untuk mengevaluasi kegagalan atau keberhasilan mereka dalam memecahkan soal matematika (Corte et al, 1996; Lester et al, 1989; Schoenfeld, 1988, 1992).

Tujuan utama pembelajaran pemecahan masalah matematis bukanlah untuk melengkapi mahasiswa dengan berbagai kumpulan kemampuan dan proses berpikir, tetapi lebih dari itu diharapkan mahasiswa dapat memanfaatkan kemampuan pemecahan masalah matematika tersebut ketika dihadapkan dengan permasalahan kehidupan keseharian (Lester, 1985). Oleh sebab itu peneliti merasa perlu untuk mengkaji lebih mendalam tentang kemampuan pemecahan masalah dan berbagai pendekatan yang dilakukan mahasiswa sebagai salah satu fokus kajian dalam penelitian ini.

Kesulitan ini juga peneliti temui selama menjadi pengajar mata kuliah statistik di IKIP PGRI Pontianak, khususnya untuk program studi non-eksak. Sebagian besar mahasiswa masih mengalami kesulitan dalam menggunakan berbagai bentuk kemampuan pemecahan masalah untuk menjelaskan ideide matematis dan memecahkan masalah matematis. Kondisi ini tentunya perlu diatasi, mengingat setiap mahasiswa tentunya harus menyelesaikan skripsi untuk memperoleh gelar sarjana yang secara pasti membutuhkan kemampuan statistik sebagai analisis hasil penelitiannya. Selain itu juga mereka adalah calon guru matematika yang seharusnya dapat mengembangkan kemampuan pemecahan masalah pada anak didiknya kelak.

Pemilihan pendekatan pembelajaran yang tepat akan menunjang pengembangan kemampuan pemecahan masalah tersebut. Salah satu altenatif pendekatan pembelajaran matematika yang diperkirakan dapat meningkatkan kemampuan pemecahan masalah mahasiswa adalah pendekatan metakognitif. Pendekatan metakognitif merupakan pendekatan pembelajaran yang menggunakan masalah terbuka serta dapat dijawab 
dengan banyak cara atau metode penyelesaian atau jawaban benar yang beragam dengan memberikan perhatian dan scaffolding. Dengan keberagaman cara penyelesaian dan jawaban tersebut, maka memberikan mahasiswa banyak pengalaman dalam menafsirkan masalah dan mungkin pula membangkitkan gagasan-gagasan yang berbeda dalam menyelesaikan suatu masalah. Hal ini tentunya akan membuka kemungkinan mahasiswa menggunakan berbagai kemampuan pemecahan masalah untuk mencari solusi dari masalah yang dihadapinya, dan dapat membantu mahasiswa melakukan pemecahan masalah secara kreatif, sehingga melalui pembelajaran dengan pendekatan metakognitif diharapkan dapat meningkatkan kemampuan pemecahan masalah matematis.

Untuk melaksanakan perkuliahan dengan menggunakan pendekatan metakognitif, diperlukan suatu strategi pembelajaran yang berorientasi pada pendekatan tersebut. Oleh karena itu peneliti termotivasi untuk melakukan penelitian dalam rangka mengefektifkan pembelajaran yang berorientasi pada pendekatan metakognitif. Strategi dengan pendekatan ini juga akan mempertimbangkan kemampuan yang akan dikembangkan, yaitu strategi heuristik yang berorientasi dan mengarahkan mahasiswa pada keterampilan pemecahan masalah matematis.

Salah satu faktor yang mempengaruhi prestasi belajar mahasiswa adalah kemandirian belajar yang dimiliki mahasiswa. Hubungan kemandirian dengan kegiatan belajar diungkapkan oleh The Liang Gie (1983:70), bahwa kemandirian belajar adalah suatu situasi yang memungkinkan seseorang memperoleh pengetahuan dan pemahaman serta keterampilan atas prakarsa atau inisiatif, kepercayaan diri dan tanggung jawabnya. Ditambahkannya, dengan adanya kenyataan kodrati manusia untuk terus belajar sepanjang hidup (long life education) maka kemandirian belajar merupakan situasi yang sangat penting, mengingat hal ini menjadi suatu kebutuhan seseorang.

Beberapa faktor yang masih sering diabaikan dalam berbagai penelitian pendidikan matematika adalah kemandirian belajar mahasiswa, termasuk kemandirian berprestasi dalam belajar matematika. Seiring dengan perkembangan dunia komunikasi, stasiun televisi berlomba-lomba menarik perhatian masyarakat, dengan acara-acara menarik yang disiarkan pada saat-saat jam belajar mahasiswa di rumah. Sebagian mereka tidak dapat menyikapi secara bijak terhadap fenomena ini, mereka menjadi kurang bersemangat dalam belajar, sebaliknya lebih semangat menonton televisi. Oleh karena itu perlu ada upaya meningkatkan kemandirian belajar mahasiswa. Menyikapi hal tersebut pentingnya penelitian dilakukan sebagai upaya untuk mengungkap informasi secara komprehensif tentang gejala-gejala yang muncul dalam praktik pembelajaran terkait kemandirian belajar mahasiswa.

\section{METODE}

Populasi penelitian ini adalah mahasiswa program studi pendidikan matematika IKIP PGRI Pontianak yang mengambil mata kuliah Analisis Data Statistik pada tahun akademik 2014-2015. Lokasi pelaksanaan penelitian ini di Sekolah Tinggi Keguruan dan Ilmu Pendidikan PGRI Pontianak. Sampel penelitian ini adalah mahasiswa semester V tahun akademik 2014-2015 yang ditentukan menggunakan cluster random sampling. Jenis penelitian ini adalah penelitian eksperimental semu dengan design faktorial $2 \times 3$.

Metode pengumpulan data penelitian meliputi metode dokumentasi, tes dan angket. Metode dokumentasi digunakan untuk 
memperoleh data dan kemampuan awal mahasiswa. Metode tes digunakan untuk memperoleh data kemampuan pemecahan masalah siswa. Metode angket digunakan untuk memperoleh data kemandirian belajar mahasiswa.

Sebelum melakukan eksperimen, dilakukan uji keseimbangan terhadap kemampuan awal matematika menggunakan uji-t. Data kemampuan pemecahan masalah matematika dianalisis menggunakan analisis variansi dua jalan dengan sel tak sama. Sebelumnya, terhadap data kemampuan awal maupun kemampuan pemecahan masalah matematika dilakukan uji prasyarat meliputi uji normalitas populasi menggunakan metode Lilliefors dan uji homogenitas variansi populasi menggunakan metode Bartlett. Selanjutnya apabila hasil analisis variansi menunjukkan $\mathrm{H}_{0}$ ditolak, dilakukan uji komparasi ganda menggunakan metode Scheffe'.

\section{HASIL DAN PEMBAHASAN}

Berikut disajikan deskripsi data kemampuan pemecahan masalah matematis mahasiswa setelah diberikannya treatment.

Tabel 1. Deskripsi Data Kemampuan Pemecahan Masalah Matematis

\begin{tabular}{|c|c|c|c|c|c|c|c|c|}
\hline \multirow{2}{*}{ Pembelajaran } & \multirow{2}{*}{$\begin{array}{c}\text { Kemandirian } \\
\text { Belajar }\end{array}$} & \multirow{2}{*}{$\mathbf{n}$} & \multicolumn{3}{|c|}{ Tendensi } & \multicolumn{3}{|c|}{ Variabilitas } \\
\hline & & & $x-54$ & Mo & Me & Min & Maks & Sd \\
\hline \multirow{3}{*}{ Metakognitif } & Tinggi & 19 & 24,26 & 22 & 22 & 22 & 30 & 3,03 \\
\hline & Sedang & 14 & 18,71 & 18 & 18 & 18 & 20 & 0,99 \\
\hline & Rendah & 16 & 13,88 & 14 & 14 & 10 & 16 & 1,86 \\
\hline \multirow{3}{*}{ Konvensional } & Tinggi & 10 & 20,20 & 16 & 20 & 14 & 28 & 4,37 \\
\hline & Sedang & 26 & 15,92 & 20 & 16 & 10 & 20 & 3,17 \\
\hline & Rendah & 13 & 15,23 & 12 & 16 & 10 & 20 & 3,52 \\
\hline
\end{tabular}

Hasil uji prasyarat diperoleh simpulan bahwa sampel berasal dari populasi yang berdistribusi normal dan mempunyai variansi yang homogen. Hasil uji keseimbangan menggunakan uji-t terhadap data kemampuan awal matematika peserta didik diperoleh simpulan bahwa populasi mempunyai kemampuan awal matematika yang seimbang. Berikut disajikan hasil analisis variansi dua jalan dengan sel tak sama.

Tabel 2. Rangkuman Analisis Variansi Dua Jalan Dengan Sel Tak Sama

\begin{tabular}{lccccc}
\hline \multicolumn{1}{c}{ Sumber } & Dk & JK & RK & F & P \\
\hline Pendekatan Pembelajaran (A) & 1 & 173,03 & 71,80 & 8,08 & 0,006 \\
\hline Kemandirian Belajar (B) & 2 & 997,31 & 412,54 & 46,42 & 0,000 \\
\hline Interaksi (AB) & 2 & 112,30 & 56,15 & 6,32 & 0,003 \\
\hline Galat & 90 & 799,85 & 8,89 & - & - \\
\hline \multicolumn{2}{c}{ Total } & $\mathbf{9 5}$ & $\mathbf{2 0 8 2 , 4 9}$ & & \\
\hline
\end{tabular}

Dari tabel di atas tampak bahwa semua nilai $F_{O b s}>F_{\alpha}$, sehingga diperoleh keputusan uji $\mathrm{H}_{0 \mathrm{~A}}$ ditolak, $\mathrm{H}_{0 \mathrm{~B}}$ ditolak dan $\mathrm{H}_{0 \mathrm{AB}}$ ditolak. Dengan demikian dapat disimpulkan bahwa: a) Mahasiswa-mahasiswa yang diberi dengan pembelajaran metakognitif dan pembelajaran konvensional mempunyai kemampuan pemecahan masalah matematika yang berbeda; b) Ketiga kate- gori kemandirian belajar mahasiswa tidak memberikan efek yang sama terhadap kemampuan pemecahan masalah matematika; c) Terdapat interaksi antara pembelajaran dan kemandirian belajar mahasiswa terhadap kemampuan pemecahan masalah matematika.

\section{Uji Komparasi Ganda}

Dari kesimpulan analisis variansi dua jalan dengan ukuran sel tak sama di 
atas menunjukkan bahwa $\mathrm{H}_{0 \mathrm{~A}}$ ditolak, $\mathrm{H}_{0 \mathrm{~B}}$ ditolak dan $\mathrm{H}_{\mathrm{OAB}}$ ditolak, sehingga perlu dicari efek signifikan uji rataan dengan uji komparasi ganda atau uji lanjut pasca anava. Teknik yang digunakan dalam uji komparasi ganda adalah dengan metode
Schefee' melalui jasa bantuan minitab. Untuk melakukan komparasi ganda, dicari terlebih dahulu rataan masing-masing sel dan rataan marginal, yang hasilnya tampak pada Tabel 3 berikut:

Tabel 3. Rataan Masing-masing Sel dan Rerata Marginal

\begin{tabular}{lcccc}
\hline \multicolumn{1}{c}{$\begin{array}{c}\text { Pendekatan } \\
\text { Pembelajaran }\end{array}$} & \multicolumn{2}{c}{ Kemandirian Belajar Mahasiswa } & \multirow{2}{*}{$\begin{array}{c}\text { Rerata } \\
\text { Marginal }\end{array}$} \\
\cline { 2 - 4 } Metakognitif & Tinggi & Sedang & Rendah & \\
\hline Konvensional & 24,26 & 18,71 & 13,88 & 19,29 \\
\hline Rerata Marginal & 20,20 & 15,92 & 15,23 & 16,61 \\
\hline
\end{tabular}

\section{Uji Komparasi Rerata Antar Baris (Pembelajaran)}

Dari hasil uji anava diperoleh bahwa $\mathrm{H}_{0 \mathrm{~A}}$ ditolak yang berarti bahwa kedua pembelajaran memberikan efek yang tidak sama atau dengan kata lain terdapat perbedaan rerata setiap pasangan baris pada masingmasing kategori pembelajaran. Selanjutnya untuk mengetahui pembelajaran mana yang lebih baik (efektif) dilihat dari reratanya.
Dari hasil analisis data dengan melihat rerata marginalnya (rerata meta-kognitif $=19,29$ ) lebih besar dari pada (rerata konvensional = 16,61) (Main effect) pada Gambar 1 dapat disimpulkan bahwa mahasiswa yang diberikan dengan pembelajaran metakognitif mempunyai kemampuan pemecahan masalah yang lebih baik dari pada mahasiswa yang diberikan dengan pembelajaran konvensional.

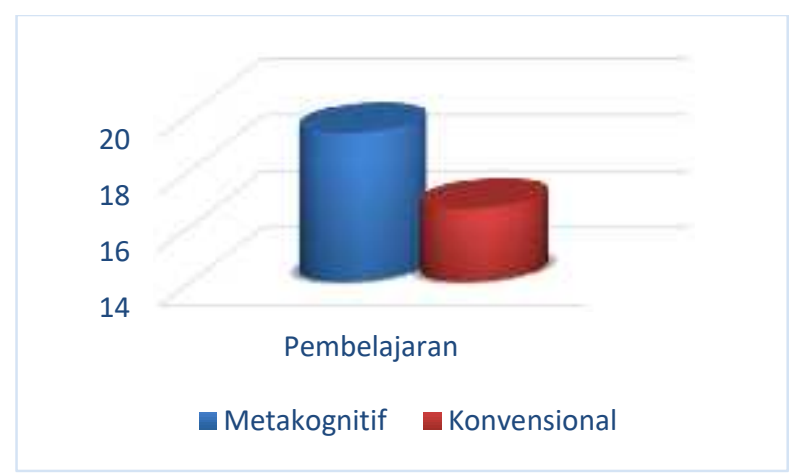

Gambar 1. Rerata Marginal Komparasi Ganda Antar Baris

Uji Komparasi Rerata Antar Kolom (Kemandirian belajar Mahasiswa)

Dari hasil uji anava diperoleh bahwa $\mathrm{H}_{0 \mathrm{~B}}$ ditolak yang berarti bahwa terdapat perbedaan rerata setiap pasangan kolom pada masing-masing tingkatan kemandirian belajar. Dalam penelitian ini, karena variabel kemandirian belajar mahasiswa mempunyai tiga kelompok (tinggi, sedang, dan rendah), maka komparasi rerata antar kolom pasca anava perlu dilakukan.

Untuk mengetahui perbedaan rerata kemampuan pemecahan masalah matematika antara mahasiswa yang mempunyai kemandirian belajar tinggi, sedang, maupun rendah maka perlu dilakukan uji komparasi ganda dengan metode Scheffe' melalui jasa bantuan minitab dan dirangkum dalam Tabel 4. 
Tabel 4. Rangkuman Komparasi Rerata Antar Kolom

\begin{tabular}{|c|c|c|c|c|}
\hline Komparasi & $\mathbf{P}$ & Keputusan & Dif & Kesimpulan \\
\hline 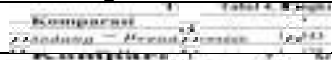 & 0,0543 & $\mathrm{H}_{0}$ diterima & 10,97 & 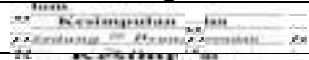 \\
\hline 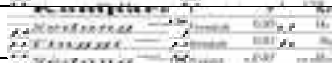 & 0,0175 & $\mathrm{H}_{0}$ ditolak & 13,41 & 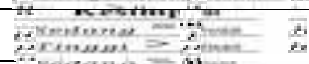 \\
\hline 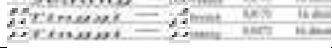 & 0,8472 & $\mathrm{H}_{0}$ diterima & 2,45 & 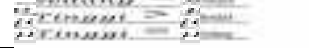 \\
\hline
\end{tabular}

Dari uji komparasi rerata antar kolom kemandirian belajar tinggi mempunyai kedengan jasa bantuan minitab pada tabel 4 di mampuan pemecahan masalah yang lebih atas diperoleh hasil sebagai berikut: 1) baik daripada mahasiswa yang memiliki Tidak terdapat perbedaan rerata yang kemandirian belajar rendah; 3) Tidak signifikan antara mahasiswa yang mem- terdapat perbedaan rerata yang signifikan punyai kemandirian belajar belajar sedang antara mahasiswa yang mempunyai kedan rendah; 2) Mahasiswa yang memiliki mandirian belajar belajar tinggi dan sedang.

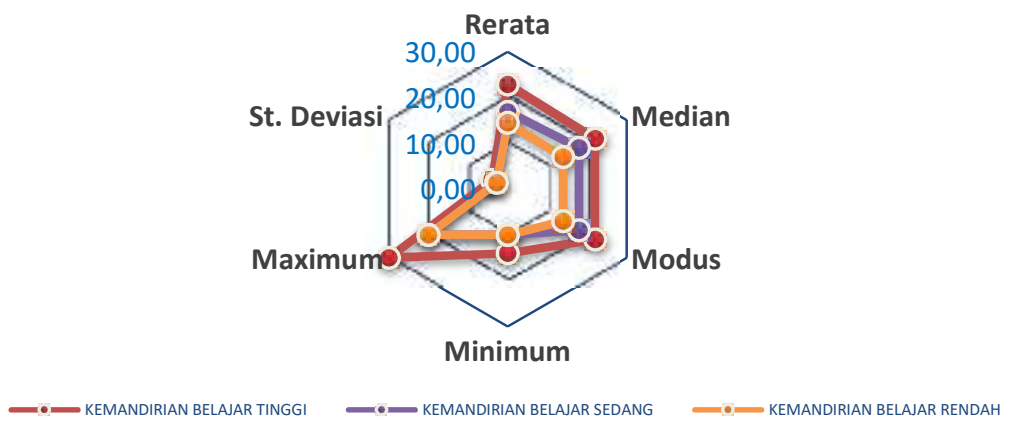

Gambar 2. Tendensi Sentral Tingkat Kemandirian Belajar

\section{Uji Komparasi Rerata Antar Sel pada Baris yang sama}

Tabel 5. Rangkuman Komparasi Rerata Antar Sel pada Baris yang sama

\begin{tabular}{ccccc}
\hline Komparasi & $\mathbf{P}$ & Keputusan & Dif & Kesimpulan \\
\hline & 0,0000 & $\mathrm{H}_{0}$ ditolak & 5,54 & \\
\hline & 0,0000 & $\mathrm{H}_{0}$ ditolak & 10,38 & \\
\hline & 0,0003 & $\mathrm{H}_{0}$ ditolak & 4,83 & \\
\hline & 0,0025 & $\mathrm{H}_{0}$ ditolak & 4,277 & \\
\hline & 0,0017 & $\mathrm{H}_{0}$ ditolak & 4,969 & \\
\hline & 0,9826 & $\mathrm{H}_{0}$ diterima & 0,692 & \\
\hline
\end{tabular}

Dari uji komparasi rerata antar sel pada baris yang sama (pada masing-masing kategori pembelajaran berdasarkan kemandirian belajar) dengan jasa bantuan minitab pada tabel 5 di atas diperoleh hasil sebagai berikut: 1) Berdasarkan kategori pembelajaran metakognitif, mahasiswa yang memiliki kemandirian belajar lebih tinggi memperoleh kemampuan pemecahan masalah matematika yang lebih baik daripada kemandirian belajar lebih rendah (Metakognitif $=$ tinggi $>$ sedang $>$ rendah); 2) Ber- dasarkan kategori pembelajaran konvensional, mahasiswa yang memiliki kemandirian belajar tinggi memperoleh kemampuan pemecahan masalah matematika yang lebih baik daipada kemandirian belajar sedang dan rendah, sedangkan kemampuan pemecahan masalah matematika mahasiswa yang memiliki kemandirian belajar sedang sama baiknya dengan kemandirian belajar rendah (Konvensional = tinggi > sedang; tinggi > rendah; sedang $=$ rendah). 


\section{Komparasi Antar Sel pada Kolom yang Sama}

Tabel 6. Rangkuman Komparasi Rerata Antar Sel pada Kolom yang sama

\begin{tabular}{ccccc}
\hline Komparasi & P & Keputusan & Dif & Kesimpulan \\
\hline & 0,0085 & $\mathrm{H}_{0}$ ditolak & 4,063 & \\
\hline & 0,0583 & $\mathrm{H}_{0}$ diterima & 2,791 & \\
\hline
\end{tabular}

Dari uji komparasi rerata antar sel pada kolom yang sama (pada masingmasing kategori kemandirian belajar berdasarkan pembelajaran) dengan jasa bantuan minitab pada tabel 6 di atas diperoleh hasil sebagai berikut: 1) Berdasarkan kategori kemandirian belajar tinggi, mahasiswa yang diterapkan dengan pembelajaran metakognitif memperoleh kemampuan pemecahan masalah matematika yang lebih baik daripada yang diterapkan dengan pembelajaran konvensional; 2) Berdasarkan kategori kemandirian belajar sedang maupun rendah, tidak terdapat perbedaan kemampuan pemecahan masalah matematika mahasiswa yang diterapkan dengan pembelajaran metakognitif dan pembelajaran konvensional.

\section{Hipotesis Pertama}

Berdasarkan hasil perhitungan pada analisis variansi dua jalan dengan ukuran sel tak sama bahwa $\mathrm{H}_{0 \mathrm{~A}}$ ditolak yang berarti terdapat perbedaan kemampuan pemecahan masalah mahasiswa antara kelompok mahasiswa yang diberikan dengan pendekatan pembelajaran Metakognitif dengan kelompok mahasiswa yang diberikan dengan pembelajaran konvensional. Dikarenakan kelompok pendekatan pembelajaran terdiri dari dua kelompok (Metakognitif dan Konvensional), untuk melihat kelompok mana yang mempunyai kemampuan pemecahan masalah yang lebih baik dapat dilihat dari rerata marginal-nya (rerata metakognitif = 19,29 dan rerata konvensional $=16,61$ ). Dengan demikian dapat diambil kesimpulan untuk hipotesis pertama, bahwa pem- belajaran matematika dengan pendekatan Metakognitif dapat memberikan kemampuan pemecahan masalah matematika yang lebih baik dari pada pembelajaran dengan pendekatan Konvensional.

Jika mengacu kepada landasan teori pada bab sebelumnya, maka dapat dilihat bahwa kedua pembelajaran adalah samasama berupaya meningkatkan kemampuan pemecahan masalah matematika mahasiswa. Pembelajaran dengan pendekatan metakognitif menekankan pada pembentukan pengetahuan dan keterampilan oleh mahasiswa sendiri maupun dalam kelompoknya, melatih kepercayaan diri dengan menyampaikan hasil kerjaannya kepada mahasiswa lainnya serta dengan melatih kemampuan kesadaran berpikir mahasiswa, sehingga potensi mahasiswa yang salah satunya adalah kemampuan berpikir kritis dan kreatif akan mampu dioptimalkan oleh Dosen. Sedangkan pada pembelajaran dengan pendekatan konvensional menekankan pada upaya optimalisasi peran Dosen untuk dalam penyampaian materinya, sehingga setiap latihan soal yang diberikan mahasiswa akan selalu mengharapkan balikan (feedback) terkait hasil pekerjaan mahasiswa terhadap soal atau tugas yang diberikan.

Kenyataan ini dimungkinkan, karena dalam pembelajaran matematika dengan menggunakan pendekatan metakognitif, paradigma pembelajaran yang berpusat pada Dosen telah bergeser pada pembelajaran yang menekankan pada aktivitas mahasiswa untuk mengkonstruksi dan merekonstruksi pengetahuannya sendiri. Sehingga mahasiswa 
lebih tertantang untuk dapat menciptakan medan strategi belajarnya masing-masing. Ini bersesuaian dengan penelitian yang dilakukan Darma (2012) yang mengungkapkan bahwa pembelajaran dengan menggunakan pendekatan metakognitif dapat meningkatkan aktivitas peserta didik, dan memberikan kesempatan pada peserta didik untuk dapat belajar secara mandiri dan mengurangi kecenderungan pembelajaran matematika yang berpusat pada tenaga pendidik (teacher/ lecturer centered).

\section{Hipotesis Kedua}

Berdasarkan hasil perhitungan pada analisis variansi dua jalan dengan ukuran sel tak sama bahwa $\mathrm{H}_{0 \mathrm{~B}}$ ditolak, ini berarti terdapat perbedaan kemampuan pemecahan masalah matematika antara mahasiswa dengan kemandirian belajar belajar tinggi, sedang, dan rendah.

Dengan ditolaknya $\mathrm{H}_{0 \mathrm{~B}}$ maka untuk melihat tingkat kemandirian belajar belajar mana yang lebih baik terhadap kemampuan pemecahan masalah matematika mahasiswa harus dilanjutkan dengan uji komparasi ganda dengan metode Scheffe'. Dari hasil uji komparasi rataan antar kolom dengan metode Scheffe' diperoleh hasil bahwa mahasiswa yang memiliki kemandirian belajar tinggi memiliki kemampuan pemecahan masalah yang lebih baik terhadap mahasiswa yang memiliki kemandirian belajar rendah, mahasiswa yang memiliki kemandirian belajar tinggi sama kemampuannya terhadap mahasiswa yang memiliki kemandirian belajar sedang, dan mahasiswa yang memiliki kemandirian belajar sedang sama baiknya dengan kemandirian belajar rendah (tinggi $=$ sedang; tinggi $>$ rendah; sedang $=$ rendah).

Secara umum dari ketiga kelompok kemandirian belajar tersebut bahwa mahasiswa yang mempunyai kemandirian belajar tinggi memiliki kemampuan pemecahan masalah yang lebih baik dari pada mahasiswa yang mempunyai kemandirian belajar rendah. Hal tersebut selaras dengan rekomendasi NCTM bahwa pemecahan masalah memotivasi peserta didik untuk belajar matematika, sehingga dapat dikatakan bahwa pembelajaran pemecahan masalah merupakan salah satu cara untuk mendorong kemandirian belajar mahasiswa. Dan dalam seminar nasional menurut Sujadi (2011) implikasinya adalah pembelajaran matematika yang berorientasi pada pemecahan masalah akan meningkatkan perkembangan intelektual peserta didik (kemandirian belajar).

\section{Hipotesis Ketiga}

Berdasarkan hasil perhitungan pada analisis variansi dua jalan dengan ukuran sel tak sama, untuk sumber variansi interaksi pendekatan pembelajaran dengan kemandirian belajar terdapat interaksi antara faktor pembelajaran dan faktor kemandirian belajar mahasiswa terhadap kemampuan pemecahan masalah matematika pada mata kuliah analisis data statistik.

Dengan demikian dikarenakan terdapat perbedaan, oleh sebab itu perlu dilakukan uji komparasi ganda antar sel pada baris yang sama. Berdasarkan hasil perhitungan melalui jasa bantuan minitab diperoleh bahwa pada masing-masing kategori pendekatan dan tingkat kemandirian belajar mahasiswa secara garis besar diperoleh hasil yang sama halnya pada hipotesis kedua, akan tetapi pada kelompok dengan pembelajaran konvensional, kemampuan pemecahan masalah mahasiswa dengan kemandirian belajar sedang sama baiknya dengan kemandirian belajar rendah, hal tersebut dapat disebabkan karena faktor pembelajaran konvensional tidak berprinsip ada proses pembelajaran yang bersifat student centered sehingga belum mampu 
meningkatkan kemandirian belajar mahasiswa.

\section{Hipotesis Keempat}

Berdasarkan hasil perhitungan pada analisis variansi dua jalan dengan ukuran sel tak sama, untuk sumber variansi interaksi pendekatan pembelajaran dengan kemandirian belajar terdapat interaksi antara faktor pembelajaran dan faktor kemandirian belajar mahasiswa terhadap kemampuan pemecahan masalah matematika pada mata kuliah analisis data statistik.

Dengan demikian dikarenakan terdapat perbedaan, oleh sebab itu perlu dilakukan uji komparasi ganda antar sel pada kolom yang sama. Berdasarkan hasil perhitungan melalui jasa bantuan minitab diperoleh bahwa pada masing-masing kategori pendekatan dan tingkat kemandirian belajar mahasiswa secara umum untuk masing-maing kemandirian belajar sedang maupun rendah tidak memiliki perbedaan terhadap kemampuan pemecahan masalah matematik mahasiswa yang diberikan dengan pembelajaran metakognitif dan konvensional. Sedangkan pada kelompok dengan kemandirian belajar tinggi, kemampuan pemecahan masalah mahasiswa dengan yang diberikan dengan pembelajaran metakognitif memiliki kemampuan pemecahan masalah matematika yang lebih baik daripada mahasiswa yang diberikan dengan pembelajaran konvensional, hal tersebut disebabkan karena kemampuan pemecahan masalah matematik merupakan kemampuan berpikir tingkat tinggi (high thingking), sesuai dengan pada pembahasan pada hipotesis pertama bahwasannya pembelajaran metakognitif merupakan pembelajaran yang berpusat pada Dosen yang menekankan pada aktivitas mahasiswa untuk mengkonstruksi dan merekonstruksi pengetahuannya sendiri. Sehingga mahasiswa lebih tertantang untuk dapat mencip- takan medan strategi belajarnya masingmasing.

\section{SIMPULAN}

Berdasarkan analisis data menggunakan analisis variansi dua jalan dengan sel tak sama, diperoleh simpulan bahwa: 1) Mahasiswa yang diberikan dengan pembelajaran metakognitif mempunyai kemampuan pemecahan masalah yang lebih baik dari pada mahasiswa yang diberikan dengan pembelajaran Konvensional; 2) Mahasiswa yang memiliki kemandirian belajar tinggi mempunyai kemampuan pemecahan masalah yang lebih baik daripada mahasiswa yang memiliki kemandirian belajar rendah, dan mahasiswa yang memiliki kemandirian belajar sedang sama baiknya dengan kemampuan pemecahan masalah mahasiswa yang memiliki kemandirian belajar tinggi dan rendah; 3) Berdasarkan kategori pembelajaran metakognitif, mahasiswa yang memiliki kemandirian belajar lebih tinggi memperoleh kemampuan pemecahan masalah matematik yang lebih baik daipada kemandirian belajar lebih rendah (Metakognitif = tinggi > sedang > rendah). Berdasarkan kategori pembelajaran konvensional, mahasiswa yang memiliki kemandirian belajar tinggi memperoleh kemampuan pemecahan masalah matematika yang lebih baik daipada kemandirian belajar sedang dan rendah, sedangkan kemampuan pemecahan masalah matematik mahasiswa yang memiliki kemandirian belajar sedang sama baiknya dengan kemandirian belajar rendah (Konvensional $=$ tinggi $>$ sedang; tinggi $>$ rendah; sedang $=$ rendah); 4) Berdasarkan kategori kemandirian belajar tinggi, mahasiswa yang diterapkan dengan pembelajaran metakognitif memperoleh kemampuan pemecahan masalah matematika yang lebih baik daipada yang diterapkan dengan 
pembelajaran konvensional. Berdasarkan kategori kemandirian belajar sedang maupun rendah, tidak terdapat perbedaan kemampuan pemecahan masalah matematik maha-

\section{DAFTAR PUSTAKA}

Cardelle, M.E. 1995. Effect of Teaching Metacognitive Skills to Student with Low Mathematics Ability. In M.J. Dunkin \& N.L. Gage (Eds.), Teaching and Teacher Education : An International Journal of Research and Studies. 8, 109-111. Oxford: Pergamon Press.

Corte, E. de, Greer, B., \& Verschaffel, L. 1996. Psychology of Mathematics Teaching and Learning, in D.C Berliner \& R.C. Calfee (Eds.), Hand Book of Educational Psychology (pp. 491-549). New York: Macmillan

Darma, Yudi. 2012. Efektivitas Strategi Heuristik Dengan Pendekatan Metakognitif dan Pendekatan Investigasi Terhadap Kemampuan Pemecahan Masalah Matematika Pada Materi Pokok Barisan dan Deret Ditinjau Dari Kreativitas Siswa Kelas XII Madrasah Aliyah di Pontianak. Tesis pada PPS UNS. Surakarta: tidak dipublikasikan.

Garofalo, J. dan Lester F. 1985. Metacognition, Cognitive Monitoring and Mathematical Performance. Journal for Research in Mathematics Education.

Gartmann, S. dan Melissa F. 2000. Metacognition and Mathematical Problem Solving : Helping Students to Ask The Right Questions. Journal The Mathematics Educator Volume 6 Number 1

Goos, et.al. 2000. A Money Problem : A Source of Insight Into Problem Solving Actioan. Queensland : The University of Queensland [online].

Kirkley, J. 2003. Principles for Teaching Problem Solving. Indiana University : Plato Learning. siswa yang diterapkan dengan pembelajaran metakognitif dan pembelajaran konvensional.

Krulik, S. \& Rudnick, J.A. 1995. The New Source Book for Teaching Reasoning and Problem Solving in Elementary School. Boston, London, Toronto: Allyn and Bacon.

NCTM. 2000. Principles and Standard for School Mathematics. Resto, Virginia: The National Council of Teachers of Mathematics, Inc.

Polya, George. 1973. How to Solve It - A New Aspect of Mathematical Method (Second edition). New Jersey : Princeton University Press

Schoenfeld, Alan H. 1980. Heuristik in the Classroom, dalam Krulik, S. dan Reys, Robert E. (Eds). Problem Solving in School Mathematics. Virginia : NCTM.

Schoenfeld, A. 1988. When Good Teaching Least to Bad Results: The Disasters of "Well-Taught"Mathematics Courses. Educational Psychologyist. 23, 145-166.

Schoenfeld, A. 1992. Learning to Think Mathematically: Problem Solving. Metacognition, and sense Making in Mathematics. In D.A. grows (Ed.), Handbook of Research on Mathematics Teaching and Learning (pp. 334-370). New York: Macmillan.

Sickafus, Ed. 2004. Heuristics for Solving Technical Problem : Theory, Derivation, Application. Grosse lle : Ntelleck LLC.

Sujadi, Imam. 2011. Implementasi Matema-tika Terhadap Perkembangan Intelek-tual Peserta Didik. Sumbawa: Disampaikan Dalam Seminar Nasional Matematika di STKIP Hamzanwadi Selong.

The Liang Gie. 1983. Cara Belajar yang Efisien. Yogyakarta: Gadjah Mada University Press. 